\title{
Weight Gain of Young Bali Cows Given Feed Quality
}

\author{
Ni Made Ayu Gemuh Rasa Astiti ${ }^{*}$, Ni Ketut Sri Rukmini ${ }^{2}$ \\ Universitas Warmadewa, Denpasar-Bali, Indonesia \\ \{ayugemuh@gmail.com ${ }^{1}$ \}
}

\begin{abstract}
Bali cattle are known to have good genetics. It is necessary to conduct research on "Weight Gain of Young Bali Cows Given Quality Feed". The research was conducted in the Abiansemal Badung Strait Village. The cattle used were 6 male Bali cows with an average age of 1 year with an average body weight of $90 \pm 9.6 \mathrm{~kg}$, which were fed elephant grass and bran with a ratio of 3: 0.5 from dry matter, without EM4 in water. drink treatment A, while treatment B with the addition of $5 \mathrm{ml} /$ liter Em4 drinking water. The research was conducted using an experimental method consisting of 2 treatments and 3 replications. Feed consumption in treatment A $3.21 \mathrm{~kg} /$ day and treatment B $3.40 \mathrm{~kg} /$ day. The results of the Ttest analysis showed that the consumption of treatment B was higher at $0.19 \mathrm{~kg} /$ head / day. on the consumption of dry matter feed in treatment A, this is due to the protein content in drinking water filled with Em4 so that the level of animal preference for the feed given is higher. Where one of the functions of Em4 is to increase the palatabality of ruminants. The average feed conversion in this study was treatment A 7.6 and treatment B 6.2. The figures in treatment A illustrate that Bali cattle in this study consume $7.6 \mathrm{~kg}$ of dry matter to increase their body weight $1 \mathrm{~kg}$. Whereas in treatment $\mathrm{B}$ requires as much as $6.2 \mathrm{~kg}$ of feed to increase $1 \mathrm{~kg}$ of body weight. The conversion rate in treatment $\mathrm{B}$ was lower than treatment $\mathrm{A}$, meaning that Bali cows that consumed drinking water supplied with EM4 resulted in a more efficient conversion than treatment A. The conversion in treatment B was lower than treatment A, meaning that Bali cows that consumed drinking water supplied with EM4 produces a more efficient conversion than treatment A. Addition of EM-4 in drinking water for one year old bulls can increase daily body weight and reduce ration consumption, and be more efficient in using rations.
\end{abstract}

Keywords: Feed Efficiency; Ration Consumption; Weight Gain, Bali Cattle

\section{Introdaction}

The change in consumption patterns due to the COVID-19 pandemic and the presence of the pig virus that attacks pigs in Bali, as well as public tastes have caused national beef consumption to tend to increase. Meat consumption data in 2017 is $1,870 \mathrm{~kg} /$ per capita / year [1]. The rate of increase in beef cattle population is not proportional to the need for beef. The cow population in 2018 was 15,633,000 heads. This population has not been able to keep up with the increasing demand for beef [2]. Various attempts were made to increase livestock production and productivity as well as the quality of carcass or meat. One of the efforts made to increase beef production is by means of a fattening program in the hope of obtaining high and efficient weight gain so that national meat needs are met [3]. Fattening is the maintenance of lean adult cows in order to increase their body weight through quality feed, in a relatively 
short time (3-5 months). One of the factors that determine the success of the final program of the fattening business is Seed [4].

Feeder cattle are young bulls (aged 1.5 - 2 years) from certain breeds of cattle, both local and imported, with body weights between $150-200 \mathrm{~kg}$ [5]. Based on the data above, to meet the national demand for meat, it is necessary to increase national meat production. Increasing national meat production can be done in two ways, namely increasing the livestock population and performance of beef cattle. The type of beef cattle that has a good performance is Bali cattle [6]. The body weight gain of Bali cattle is $0.5 \mathrm{~kg} /$ day while PO cattle are $0.78 \mathrm{~kg} /$ day. Improving the performance of cows can be done by arranging rations that are balanced and in accordance with their nutritional needs. Good rations have high digestibility so that they are easily absorbed by livestock and efforts to increase digestibility in the rumen are often added with feed additives. One of the feed additives that is currently popular in increasing production is probitik [7].

Probiotics contain components needed by livestock such as vitamins and enzymes as well as mannanoligisaccharides which can boost the immune system of livestock. Probiotics are feed additives in the form of live microbes that can improve the balance and digestive function of animals, as well as improve health conditions and increase livestock productivity [8]. There are three types of live microbes that are safe for livestock consumption: bacteria, protozoa, and fungi. There are many kinds of probiotics in animal feed, one of which is "EM4" which contains the bacteria Bacillus subtilis, Lactobacillus plantarum and Bacillus megaterium. These bacteria provide the advantage of increasing fermentation efficiency in the rumen, increasing digestibility of forage and increasing the flow rate of rumen microbial protein [9]. With the probiotic daily body weight gain (Average Daily Gain = ADG) and the percentage of carcass is higher

Based on these thoughts, it is necessary to conduct research on the weight gain of one year old male bali cattle which are given additional EM4.

Does the provision of EM4 probiotic to the drinking water of one year old male bali cows can improve the performance of Bali cattle, which include daily body weight gain and feed consumption, feed consumption and efficiency. to determine the daily body weight gain of male bali cows given EM4 probiotic. to determine the feed conversion of male Bali cows given EM4 probiotic. Benefits of Research As information for Balinese cattle breeders in the use of probiotics. As information material for researchers and academics how much influence the addition of probiotics in drinking water has on the increase in body weight of male Bali cows.

\section{Method}

The research was conducted in the Selat village of Badung Regency, for 60 days, from 24 June 2020 to 23 August 2020. The cattle used in this study were 6 male Bali cows with an average age of 1 year with an average body weight of $90 \pm 9.6 \mathrm{~kg}$. The feed used in this study consisted of forage and bran with a ratio of 3: 0.5 from dry matter. The content of feed nutrients can be seen in the table. 1 
Tabel 1. Kandungan Nutrien Pakan

\begin{tabular}{llllll}
\hline Bahan Pakan & BK\% & BO (\%BK) & PK (\%BK) & LK (\%BK) & SK (\%BK) \\
\hline Rumput Gajah & 18,96 & 82,68 & 9,48 & 2,12 & 29,74 \\
Dedak Padi & 88,97 & 89,85 & 10,93 & 8,90 & 15,07 \\
\hline
\end{tabular}

Hasil analisis Laboratorium [9].

The research was conducted using an experimental method consisting of 2 treatments and 3 replications. The treatments given were: $\mathrm{P} 1=\mathrm{Control}$ (forage + bran with a ratio of 3: 0.5 in dry matter) without EM4 in drinking water. P2 $=$ (forage + bran with a ratio of 3: 0.5 in dry matter) with EM4 1 teaspoon mixed into 1 liter of drinking water.

Consumption of rations

Ration consumption is obtained by reducing the ration material provided with the leftover ration material. Measurement of ration consumption was carried out every day during the study.

Increase in Body Weight

Daily weight gain can be found using the formula according to Cole, 1996, namely:

B2-B1

$$
\mathrm{PBBH}(\mathrm{Kg})=\quad \text { W2-W1 }
$$

$\mathrm{PBBH}=$ Average daily body weight gain

B1 = Body weight at initial weighing

B2 = Weight at final weighing

W1 = Time of initial weighing

W2 = final weighing time.

\section{Feed conversion}

The formula for calculating FCR is:

$\mathrm{FCR}=$ Amount of feed consumed $(\mathrm{kg})$ divided by

The resulting body weight $(\mathrm{kg})=$ (final study weight-initial study weight)

Calculating feed conversion using the formula:

$$
\text { Konversi pakan }=\frac{\text { Total Feed Consumption }(\mathbf{B} \mathbf{K})}{\text { Average daily body weight }(\mathrm{Kg})}
$$

Calculating feed efficiency with the formula:

Feed efficiency(\%)

$$
\frac{=\mathrm{PBBH}}{\text { Consumption of FEED }(\mathrm{bk})} \rightarrow(\mathbf{1 0 0 \%})
$$

Information:

PBBH : Daily weight gain

BK : Dry Weight

The data obtained during the study were analyzed statistically using the T-test. 


\section{Results and Discussion}

This research was conducted at Sari Sedana Farmers Group, strait village, Abian subdistrict, Badung Bali. The cattle used were 12 months old male Bali cattle with an average body weight of $90 \pm 9.6 \mathrm{~kg}$. The feed given to treatment A cows is $100 \%$ field grass (elephant grass) and treatment $\mathrm{B}$ is in the form of mixed feed, namely $85 \%$ elephant grass and $15 \%$ field grass. The amount of feed is calculated based on 3.5\% of body weight (consisting of 3\% forage and $0.5 \%$ bran). The feed used in this study was taken directly by the farmer near the cage so that the feed was still fresh. Feeding is done 2 times a day and drinking water is given 2 times a day. Drinking water given to livestock is water taken from a trench filled with EM4.

Tabel 3. PBBH Feed Consumption, Conversion, and Efficiency of Young Bali Cows fed elephant grass and rice bran.

\begin{tabular}{clcc}
\hline & & \multicolumn{2}{c}{ Treatment } \\
\cline { 3 - 4 } NO & Variable & A & B \\
& & 3.21 & (Without EM4) \\
\hline \multirow{2}{*}{1} & Consumption of BK Rations (Kg/ & 0,45 & 3.40 \\
2 & head / day) & 7.6 & 0.52 \\
3 & CBBH (Kg / tail / day) & 0.13 & 6.2 \\
4 & Efficiency & & 0.16 \\
\hline Source: Primary data processed (2020).
\end{tabular}

Feed consumption is the amount of feed consumed by animals. The amount of feed consumption is a factor that determines the amount of nutrients obtained by livestock and affects the level of production. Feed consumption is one of the best indicators of livestock production. Feed consumption is the difference between the amount of feed and the amount of leftover feed, the amount of feed consumption affects the amount of nutrients that enter the body of the animal. The average feed consumption in treatment A was $3.21 \mathrm{~kg} /$ day and in treatment B $3.40 \mathrm{~kg} /$ day. The results of the Ttest analysis showed that the consumption of treatment B was higher at $0.19 \mathrm{~kg} /$ head / day. on the consumption of dry matter feed in treatment A male Bali cattle aged one year, this is due to the protein content in drinking water filled with Em4 so that the level of animal preference for the feed given is higher. Where one of the functions of Em4 is to increase the palatabality of ruminants [20]. The ability of ruminants to consume a given ration is influenced by the factor of the ration given which includes the composition of the nutrients in the ration. Theoretically, BK consumption is generally $3 \%$ of body weight, but the results of research in treatment $\mathrm{A}$ show that the feed consumption of treatment A $(3.21 \mathrm{~kg} /$ head / day of average body weight and treatment B $(3.40 \mathrm{~kg} /$ head / day) ) of the average body weight. Although the consumption of BK in this study was higher than the theoretical BK consumption (3\%), it was still able to provide an average body weight gain higher than $0.5 \mathrm{~kg} /$ head / day [15]

This shows that the two feeds have high nutritional content and that the anti-nutritional effect of the two types of feed in the research Bali cattle does not have a negative impact on their production. Measurement of feed consumption is influenced by, feed palatability and selection of forage. Feed consumption also has a relationship with livestock energy needs which often causes the consumption of animal feed to be different [24]. Low feed 
consumption will cause a deficiency of nutrients needed by livestock and consequently will inhibit the accumulation of fat and meat. If the needs for basic life have been met, the excess nutrients consumed will be stored as fat and meat tissue. Feed consumption is a basic factor for life and determines production. Some of the factors that affect the level of consumption are the type of livestock, the food provided (palatability), and the environment in which the animals are kept. The ability of rumunants to consume rations is influenced by several factors, namely: 1. The livestock factor itself includes body size or body weight, genetic potential, physiological status, production level and livestock health. 2. The ration factors that are given, include form and nature, composition of nutritional substances, frequency of administration, balance of nutritional substances and content of toxic and anti-nutritional substances. 3. Other factors include temperature and humidity, rainfall, length of day or night as well as the state of the cage room and ration area [25].

Daily Weight Gain $(\mathrm{PBBH})$. Berat badan merupakan suatu kriteria pengukuran yang penting pada seekor hewan dalam menentukan perkembangan pertumbuhannya dan merupakan salah satu dasar pengukuran untuk produksi disamping jumlah anak yang dihasilkan dalam menentukan nilai ekonominya [26]. Pertambahan bobot badan adalah kemampuan ternak untuk mengubah zat-zat nutrisi yang terdapat dalam pakan menjadi daging. Pertambahan bobot badan merupakan salah satu peubah yang dapat digunakan untuk menilai kualitas bahan makanan ternak [25 ]. Pertambahan bobot badan ternak ruminansia dipengaruhi oleh kualitas dan kuantitas pakan, penilaian pertambahan bobot badan ternak sebanding dengan ransum yang dikonsumsi. Pertambahan bobot badan dipengaruhi oleh beberapa faktor antara lain total protein yang diperoleh setiap harinya, jenis ternak, umur, keadaan genetis, lingkungan, kondisi setiap individu dan manajemen tata laksana. Tabel 3 menunjukkan bahwa ransum perlakuan tidak menyebabkan perbedaan yang sangat nyata. Rata-rata pertambahan bobot badan harian perlakuan A $0,52 \mathrm{~kg} /$ hari dan perlakuan B $0,45 \mathrm{~kg} /$ hari dari data tersebut terlihat bahwa ada kecenderungan ternak sapi yang mengkonsumsi air minum yang diisi EM4 sedikit lebih tinggi bobot badannya dibandingkan perlakuan A. Lebih tingginya rata-rata konsumsi perlakuan B dibanding perlakuan B, menunjukkan bahwa tingkat palatabilitas perlakuan B lebih baik dibandingkan perlakuan A. Aroma air minum yang diisi EM4 pada perlakuan B diduga menyebabkan total konsumsi perlakuan B lebih tinggi. Selain itu terdapat kemungkinan bahwa didalam rumen sapi yang digunakan dalam penelitian terdapat mikroba yang mampu mendetoksifikasi mimosin, sehingga tidak membahayakan bagi pertumbuhan ternak. Berat badan ternak sangat dipengaruhi oleh konsumsi pakan, kandungan nutrisi dalam pakan, ada tidaknya zat anti nutrisi dan palatabilitas pakan. Kualitas dan kuantitas pakan sangat mempengaruhi pertambahan bobot badan ternak. PBBH hasil penelitian ini tidak jauh berbeda dengan laporan peneliti terdahulu, yakni berkisar 0,05-0,4 kg/ekor/hari [27]. Dalam larutan EM4 juga terdapat ragi dan jamur yang dapat mengubah nitrogen bukan protein menjadi protein bakteri dan jamur dapat menghasilkan enzim yang memiliki aktivitas dalam melonggarkan ikatan lignoselulosa dan lignohemiselulosa, sehingga protein yang terikat pada lignin akan terlepas [24].

Body weight is an important measurement criterion in an animal in determining the development of its growth and is one of the measurement bases for production in addition to the number of children produced in determining its economic value [26]. Body weight gain is the ability of livestock to convert nutrients found in feed into meat. Body weight gain is one of the variables that can be used to assess the quality of animal feed ingredients [25]. The body weight gain of ruminants is influenced by the quality and quantity of feed, the assessment of the body weight gain of livestock is proportional to the ration consumed. The increase in body weight is influenced by several factors, including the total protein obtained each day, type of 
livestock, age, genetic condition, environment, the condition of each individual and management management. Table 3 shows that the treatment rations did not cause a very significant difference. The average daily body weight gain of treatment $\mathrm{A}$ is $0.52 \mathrm{~kg} /$ day and treatment B is $0.45 \mathrm{~kg} /$ day. From these data, it can be seen that there is a tendency for cows to consume drinking water filled with EM4 slightly higher in body weight than treatment A. The high average consumption of treatment $\mathrm{B}$ compared to treatment $\mathrm{B}$, indicates that the level of palatability of treatment $B$ is better than treatment $A$. The aroma of drinking water filled with EM4 in treatment B is thought to cause the total consumption of treatment $B$ to be higher. In addition, there is a possibility that in the rumen of the cattle used in the study there are microbes that can detoxify mimosin, so that it is not harmful to livestock growth. Animal body weight is strongly influenced by feed consumption, nutritional content in feed, presence or absence of anti-nutritional substances and feed palatability. The quality and quantity of feed greatly affects the weight gain of livestock. The PBBH results of this study were not much different from previous research reports, which ranged from $0.05-0.4 \mathrm{~kg} /$ head / day [27]. In the EM4 solution there are also yeasts and fungi that can convert nitrogen instead of protein into bacterial protein and fungi can produce enzymes that have activity in loosening lignocellulose and lignohemicellulose bonds, so that the protein bound to lignin will be released [24].

Feed conversion is the ratio or ratio between the amount of feed consumed by livestock and the products produced by these livestock. Feed conversion is the amount of feed consumed to get an increase in live weight units. . The average feed conversion in this study was treatment A 7.6 and treatment B 6.2. The figures in treatment A illustrate that Bali cattle in this study consume $7.6 \mathrm{~kg}$ of dry matter to increase their body weight $1 \mathrm{~kg}$. Whereas in treatment $\mathrm{B}$ requires as much as $6.2 \mathrm{~kg}$ of feed to increase $1 \mathrm{~kg}$ of body weight. The conversion rate in treatment $\mathrm{B}$ was lower than treatment $\mathrm{A}$, meaning that Bali cows that consumed drinking water supplied by EM4 (treatment B) resulted in a more efficient conversion than treatment $\mathrm{A}$. The low conversion rate in treatment $\mathrm{B}$ indicated that giving Em4 to drinking water caused an increase in falatabelity, so that the use of ration in treatment $\mathrm{B}$ is more efficient. Feed metabolism and absorption in the rumen run optimally, because there is an adequate and balance of feed nutrients needed by livestock. Efficient feed requires less dry matter to produce weight gain. The greater the conversion of livestock, the inefficient in using rations to increase body weight gain.

Efficiency is the ratio between body weight gain and ration consumption. The results showed the efficiency in treatment A 0.13 and treatment B 0.16 . the higher the efficiency rate, the less efficient the livestock is in converting feed into meat. The efficiency of feed use is influenced by several factors including the ability of livestock to digest feed ingredients, the adequacy of feed substances for basic life, growth, body function, and the type of feed used [28]. Production efficiency is closely related to production costs, the lower the feed conversion value, the higher the efficiency of feed use [27], [28]. High crude fiber in feed will cause the digestibility to be small, so that feed conversion is an integration of digestibility. Feed conversion, especially in ruminants, is influenced by the quality of the feed, the amount of body weight gain and the digestibility value. Good quality feed will increase livestock growth. Ration consumption is one measure to determine efficiency [29]. 


\section{Conclusions}

Based on the results that have been achieved, it can be concluded that: The addition of EM-4 in drinking water for one year old bulls can increase daily body weight and reduce ration consumption. The addition of EM-4 in drinking water for one year old bulls is more efficient in the use of rations. It is recommended to increase the level of addition of EM-4 in drinking water so that it is known to what level the provision of EM4 in drinking water is able to have a positive effect on body weight gain and ration consumption and the length of time of the study is extended more than 2 months.

\section{References}

[1] Dinas Peternakan Dan Kesehatan Hewan Sumbawa. 2016. Perkembangan Populasi Ternak Besar Selama 5 Tahun (Ternak Rakyat Dan Pemerintah). Http://Www.Disnaksumbawa.Com(Diakses 05 Oktober 2020).

[2] Muladno. 2012. Aplikasi Teknologi Perbibitan Untuk Peningkatan Produksi Bakalandankualitasdagingsapinasional.Prosidingseminarnasional Peningkatan Produksi Dan Kualitas Daging Sapi Bali Nasional. Bali, 14 September 2012

[3] Diwyanto, K. Dan L. Praharani. 2010. Reproduction Management And Breeding Strategis To Improve Productivity And Quality Of Cattle. Abstracts International Seminar Conservation And Improvement Of World Indigenous Cattle. 3rd-4th September. Udayana University, Denpasar Bali, Indonesia.

[4] Astiti, Ni Made Ayu Gemuh Rasa. 2018. Pengantar Ilmu Peternakan. Warmadewa University Press, Denpasar. Bali.

[5] Sasongko Wijoseno Rusdianto1, Heny Ks Daryanto2, Kuntjoro2 Dan Atien Priyanti. 2015. Pengaruh Perubahan Harga Sapi Terhadap Permintaan Input Dan Penawaran Output Usaha Penggemukan Sapi Bali. Informatika Pertanian, Vol. 24 No.2, Desember $2015: 223-232$

[6] Astiti, Ni Made Ayu Gemuh Rasa. 2018. Sapi Bali Dan Pemasarannya. Warmadewa University Press Denpasar.

[7] Partama, I. B. G., T. G. O. Susila, I. W. Suarna Dan I. M. Suasta. 2003. Peningkatan Produktivitas Sapi Bali Kereman Melalui Suplementasi Mineral Dalam Ransum Berbentuk Wafer Yang Berbasis Jerami Padi Amoniasi Urea. Laporan Penelitian Proyek Pengkajian Teknologi Partisipatif. Bptpqbali.

[8] Diky Pamungkas Dan Yenny Nur Angraeni.2006. Wartazoa Vol 16 No.2.

[9] Habib Ali Zamzami, Hermawan Dan Lia Budimulyati Salman. 2015. The Effect Of Using Probiotic In Complete Feed On Quantity And Quality Of Milk Production Lactating Dairy Cows. Fakultas Peternakan Universitas Padjajaran Bandung.

[10] Astiti, Ni Made Ayu Gemuh Rasa Astiti. 2018. Pengantar Ilmu Peternakan. Warmadewa University Press. Denpasar.

[11] Press Release Direktur Jenderal Peternakan Dan Kesehatan Hewan. 2012. Supplydemanddagingsapi/Kerbausaampaidengandesember2012.

[12] Adiwinarti, R., U.R. Fariha Dan C.M.S. Lestari. 2011. Pertumbuhan Sapi Jawa Yang Diberi Pakan Jerami Padi Dan Konsentrat Dengan Level Protein Berbeda.Jurnal Ilmu Ternak Dan Veteriner. Pusat Penelitian Dan Pengembangan Peternakan 16(4): 260-265 
[13] Suryani, N. N. 2012. Aktivitas Mikroba Rumen Dan Produktivitas Sapi Bali Yang Diberi Pakan Hijauan Dengan Jenis Dan Komposisi Berbeda. Disertasi. Program Pascasarjana Universitas Udayana. Denpasar

[14] Rasyidah Mappanganro , Muh.Basir Paly, Khaerani Kiramang Dan Rifaldi Nurhidayat. 2018. Pengaruh Pemberian Alga Coklat (Sargassum Sp.) Terhadap Pertambahan Berat Badan Sapi Bali Jantan. Jiip Volume 4 Nomor 2: 139-148, Desember 2018 Jurnal Ilmu Dan Industri Peternakan.

[15] Sarwono, B Dan H.B. Arianto. 2007. Penggemukan Sapi Potong Secara Cepat. Penebar Swadaya. Jakarta.

[16] Romjali, E. 2018. Pengembangan Inovasi Sapi Potong Melalui Pendekatan Laboratorium Lapang. Wartazoa Vol $28 \quad$ (2): 069 - $080 . \quad$ Doi: Http://Dx.Doi.Org/10.14334/Wartazoa.V28i2.1797

[17] Siregar, S. B. 2008. Penggemukan Sapi. Edisi Revisi. Penerbit Penebarswadaya, Depok. Cetakan XVII.

[18] Suryani, N. N. Dan N, P. Mariani. 1996. Penampilan Sapi Bali Jantan Muda Yang Diberi Pakan Berbagai Hijauan Dengan Dan Tanpa Konsentrat. Laporan Hasil Penelitian Kerja Sama IAEUP Dengan Fakultas Peternakan.Denpasarqbali.

[19] Suryani,N.N.,Iwayansuarna,Igedemahardika,Danniputusarini,2019. Studi Peningkatan Kualitas Daging Sapi Bali. Laporan Penelitian Kerjasama Bappedalitbang Propinsi Bali Dengan Lembaga Penelitian Dan Pengaabdian Kepada Masyarakat Universitasudayana.

[20] Suryani,N.N.,Iwayansuarna,Igedemahardika,Danniputusarini,2017. Effectofincreasingenergyandproteinrationonnutrientdigestibility Andperformanceofbaliheifercalves.Prosidingthe2ndinternational Conference On Animal Nutrition And Environment (ANIQNUE2017). Thailand.

[21] Anonimous. Manfaat Dan Kegunaan EM4.

[22] Https://8villages.Com/Full/Petani/Article/Id/5e815f1 f06a2c948309758ad\#: :Text=Dalam \%20bidang\%20pertanian $\% 2 \mathrm{C} \% 2$.

[23] Rian Ardiansyah.2018. Pengaruh Level Penggunaan Em4 Pada Fermentasi Campuran Darah Dan Dedak Padi Terhadap Kandungan Protein Dan Serat Kasar. Skripsi Fakuktas Peternakan Universitas Mataram Lombok.

[24] Wibawa A.A.P., Wirawan I W., Dan Partama I. B. G. 2015. Peningkatan Nilai Nutrisi Dedak Padi Sebagai Pakan Itik Melalui Biofermentasi Dengan Khamir. Majalah Ilmiah Peternakan Vol. 18. No. 1. ISSN : 0853-8999.

[25] Dutta, T.K ., S .S . Kundu And D .D . Sharma. 2001 . Potential Of Probiotic Supplementation On In-Vitro Rumen Fermentation And $35 \mathrm{~S}$ Incorporation In Microbial Protein . Indian J . Anim . Nutr . 18 : 227 - 234.

[26] Fitriah. 2013. Pertambahan Berat Badan Sapi Bali Pada Umur Berbeda Yang Dipelihara Secara Intensif. Skripsi. Fakultas Peternakan Universitas Hasanuddin. Makassar

[27] Abrianto, P. 2011. Cara Mengolah Gamal Untuk Dijadikan Pakan Ternak Sapi. Http://Www.Duniasapio.Com. Diakses Pada Tanggal 2 November 2020.

[28] Rian Ardiansyah.2018. Pengaruh Level Penggunaan Em4 Pada Fermentasi Campuran Darah Dan Dedak Padi Terhadap Kandungan Protein Dan Serat Kasar. Skripsi Fakuktas Peternakan Universitas Mataram Lombok.

[29] Batubara, L. P., Ginting, S. P. Doloksaribu Dan M. Junjungan. 2004. Pengaruh Kombinasi Bungkil Inti Sawit Dengan Lumpur Sawit Serta Suplementasi Molases Terhadap Pertumbuhan Kambing Potong. Prosiding Seminar Nasional Teknologi Peternakan Dan Veteriner: 170-177. 
[30] E.L. Aditi, R. Priyanto, M. Baihaqi, B.W. Putra1 \& M. Ismail.2013. Performa Produksi Sapi Bali Dan Peranakan Ongole Yang Digemukan Dengan Pakan Berbasis Sorghum. Jurnal Ilmu Produksi Dan Teknologi Hasil Peternakan ISSN 2303-2227. Vol. 01 No. 3, Oktober 2013 Hlm: 155-159. 